画像所見から術前診断が可能であった腸間膜デスモイドの 1 例

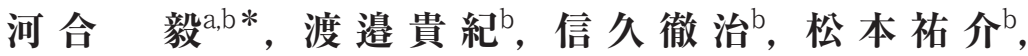 \\ 甲斐恭平 ${ }^{\mathrm{b}}$ ，佐藤 四三 ${ }^{\mathrm{b}}$
}

阔山大学大学院医歯薬学総合研究科 消化器外科学 $\mathrm{a}$, 姫路赤十字病院 外科 $\mathrm{b}$

\title{
A case of a mesenteric desmoid tumor preoperatively distinguished from imaging findings
}

\author{
Takashi Kawai $^{\mathrm{a}, \mathrm{b} *}$, Takanori Watanabe ${ }^{\mathrm{b}}$, Tetuji Nobuhisa ${ }^{\mathrm{b}}$, Yusuke Matumoto ${ }^{\mathrm{b}}$, \\ Kyohei Kai ${ }^{\mathrm{b}}$, Shiso Sato ${ }^{\mathrm{b}}$

\begin{abstract}
aDepartment of Gastroenterological Surgery Transplant and Surgical Oncology, Okayama University Graduate School of Medicine, Dentistry and Pharmaceutical Sciences, Okayama 700-8558, Japan,

${ }^{b}$ Department of Surgery, Japanese Red Cross Society Himeji Hospital, Hyogo 670-8540, Japan
\end{abstract}

\begin{abstract}
A 73-year-old woman was admitted for closer investigation into an abdominal tumor. Abdominal ultra-sonography, $\mathrm{CT}$, and magnetic resonance imaging showed a discrete abdominal tumor. Especially on MRI, the tumor appeared as a relatively ill-defined whorled soft-tissue thickening within the mesenteric fat, causing angulation or speculation of adjacent bowel mesentery. Surgery was performed under a presumptive diagnosis of a mesojejunum desmoid. The tumor was invading the transverse mesocolon and mesojejunum as well as the third portion of the duodenum and the middle colic artery, and it was close to but apart from the superior mesenteric artery. The tumor was resected, including removal of part of the duodenum and transverse colon. The specimen contained a white solid tumor measuring $14 \times 12 \times 8 \mathrm{~cm}$. Pathologic examination showed differentiated fibroblasts and copious collagen fibers. The tumor was negative for CD34, c-kit, S-100, and $\alpha$-SMA, but positive for $\beta$-catenin. On the basis of these findings, we established a diagnosis of mesenteric desmoid tumor of the small intestine. The patient has been followed postoperatively for 2 years, no sign of recurrence, to date.
\end{abstract}

キーワード：腸間膜腫瘍（mesenteric tumor）デスモイド（desomoid），小腸間膜（mesentery of the small intestine）

\section{緒 言}

腸間膜デスモイドは稀な疾患で術前診断は困難である. 今回我々は画像所見から腸間膜デスモイドを疑い小腸大量 切除を回避しえた 1 例を経験したので報告する.

\section{症例}

症 例 : 73歳女性.

主 訴：特になし。

現病歴：健診の腹部超音波検査で腹腔内腫瘤を指摘され， 精査加療目的に紹介となった。

既往歴：特になし.

家族歴：特になし。

身体所見：身長 $143 \mathrm{~cm}$ 体重 $42 \mathrm{~kg}$. 眼球結膜貧血黄疸なく, 表 在リンパ節触知せず。臍右下に平滑で硬く可動性のない腫

平成29年 9 月 22 日受理

* 个670-8540 兵庫県姫路市下手野 1 丁目 12 番 1 号

電話：079-294-2251 FAX : 079-296-4050

E-mail : takaraka7954@hotmail.com
瘍を触知した。

血液検查所見：腫瘍マーカーを含む血液，生化学，尿所見 に異常を認めず.

腹部超音波検查：臍右下に可動性不良な $50 \times 23 \mathrm{~mm}$ の境界明 瞭な低エコー腫瘤を認めた。

腹部造影 CT：30×50mmの境界明暸で内部はほぼ均一な腫 瘍が，中結腸動脈と上腸間膜動脈に接し，中心部により強 い造影効果を認めた。冠状断では辺縁は鋸歯状を呈し十二 指腸の一部が巻き込まれていた（図 1 ).

腹部 MRI：T 1 強調画像で低信号（図 $2 \mathrm{a}$ ), T 2 で高信号 から低信号を呈した。また，造影 CT と同様に辺縁は鋸歯 状変化を呈し間膜脂肪織を強く卷き込むような所見と呈し た (図 $2 \mathrm{~b})$.

以上より GIST，悪性リンパ腫を鑑別に腸間膜デスモイ ドを第一に疑い手術を施行した。

手術所見：腫瘍は横行結腸，結腸間膜と上腸間膜に浸潤し 中結腸動脈と十二指腸下降脚を巻き込んでいたため, 横行 結腸と十二指腸は部分切除を施行した。 上腸間膜動脈との 境界は不明瞭であったが。 小腸大量切除を回避するため, 
上腸間膜動脈とは可及的に剥離した（図 3 ).

切除標本： $64 \times 42 \times 27 \mathrm{~mm}$ の灰白色の充実性腫瘍で中心部に 十二指腸管腔を確認した（図 4 ).
病理組織診断：腫瘍細胞は楕円形の核と両染性の胞体をも つ細長い紡錘形で myofibro-blast の形態で, 膠原線維と緩 やかな束をなし増生していた。CD34，c-kit，s-100蛋白，
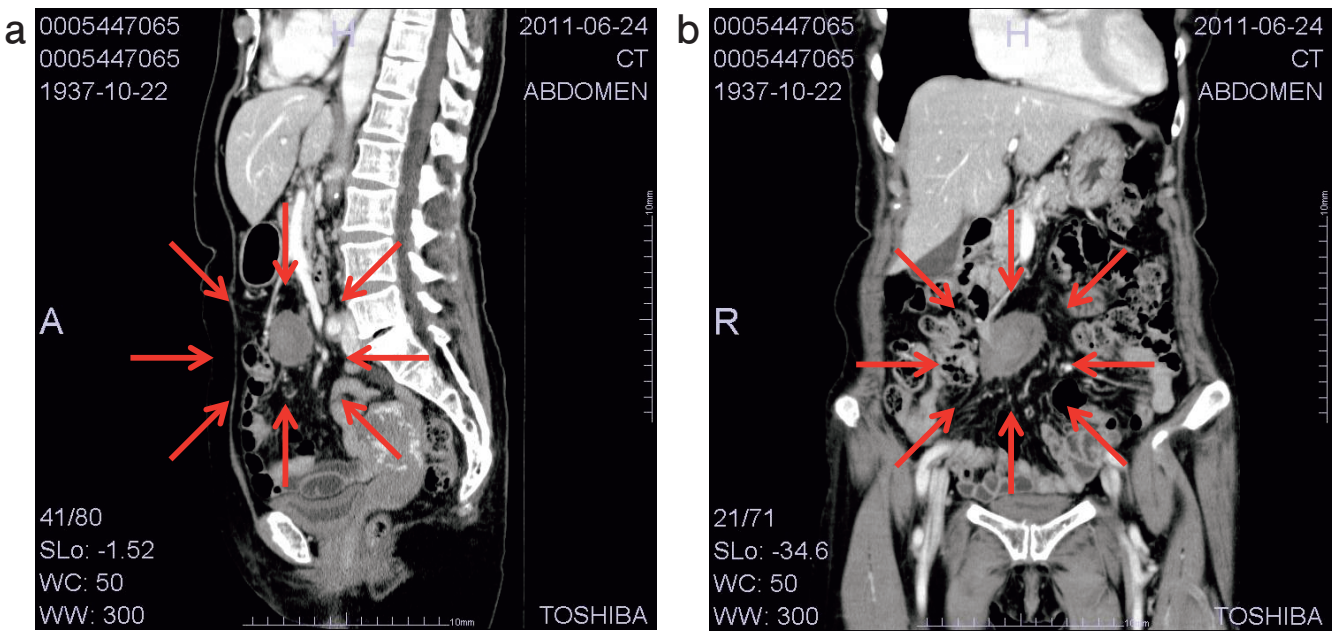

a
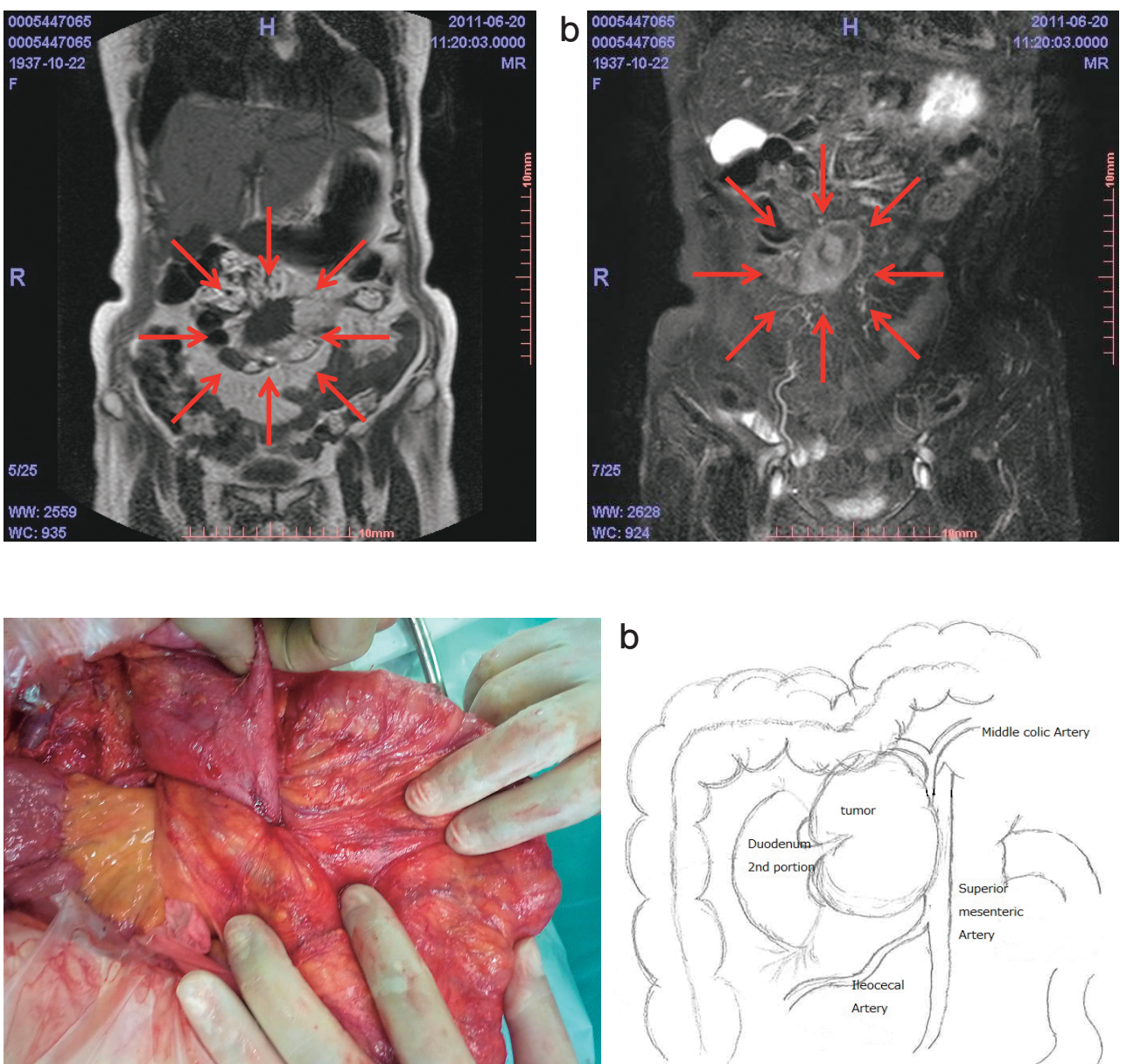

a
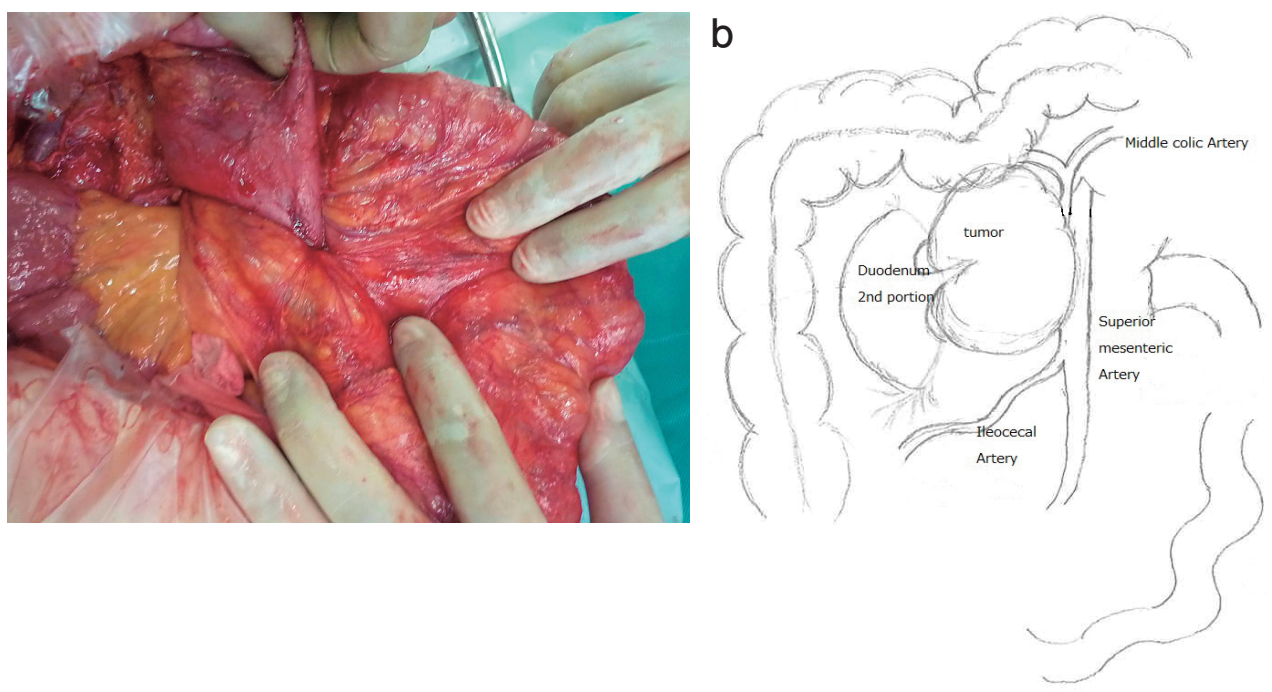

図 1 腹部造影 $\mathrm{CT}$

$\mathrm{a}:$ 矢状断. $30 \times 50 \mathrm{~mm} の$ 境 界明瞭で内部はほほ均一 な腫瘍が, 中結腸動脈と上 腸間膜動脈に接し，中心部 により強い造影効果を認 めた。 b : 冠状断。辺縁は 鋸歯状を呈し十二指腸の 一部が巻き込まれていた。

\section{図 2 腹部 MRI}

$\mathrm{a} ： \mathrm{~T} 1$ 強調画像. 腫瘍は 低信号を呈した。 b：T2 強調画像。腫瘍は高信号か ら低信号を呈した。また， 造影 $\mathrm{CT}$ と同様に辺縁は 鋸歯状変化を呈し間膜脂 肪織を強く巻き込むよう な所見と呈した.

\section{困 3 手術所見}

a : 術中写真. 腫瘍は横行結 腸，結腸間膜と上腸間膜に浸 潤していた。 b : シェーマ. 腫瘍は中結腸動脈と十二指腸 下降脚を巻きこみ，上腸間膜 動脈との境界は不明瞭であっ た。 
$\alpha$-SMA は陰性， $\beta$-catenin は陽性であった。腸間膜デスモ イドと診断した (図 5 ). 腫瘍と周囲組織の境界は不明瞭で 十二指腸と横行結腸にはそれぞれ固有筋層まで一部浸潤を 認めた。

術後経過：術後第18病日に退院となり, 術後 2 年現在再発 の兆候は認められない.

\section{考察}

腸間膜腫瘍は，間膜中央に位置し細い茎で後部腹壁に固

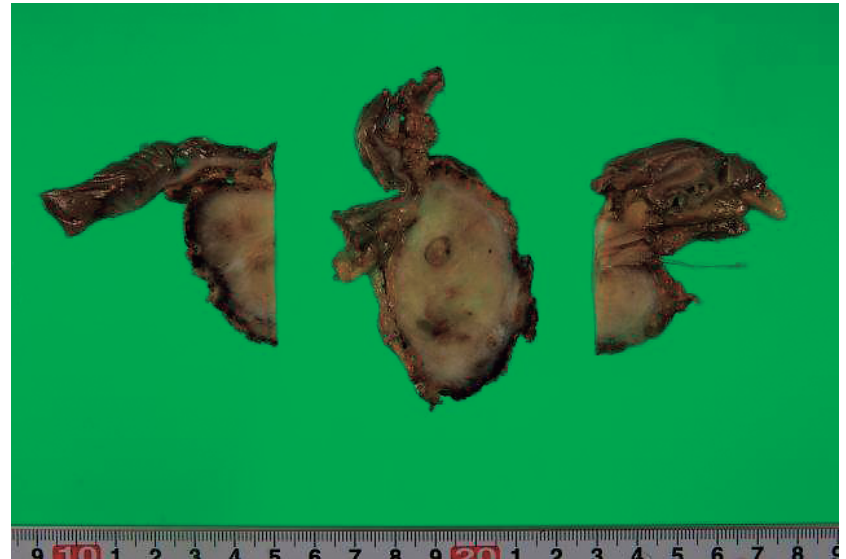

図 4 切除標本

腫瘍は $64 \times 42 \times 27 \mathrm{~mm}$ の灰白色の充実性腫瘍で中心部に十二指腸 管腔を確認した.
定され可動性のある腸間膜型，広い底面を有し大部分が後 部腹壁に存在し非可動性の後腹膜型，その中間を中間移行 型とし ${ }^{1)}$ ，自験例は中間移行型となる。頻度は，82万人中 25例 ${ }^{2}$ で，悪性は線維肉腫（22\%)，良性は線維腫（30\%） の頻度が高い3)。

デスモイドは線維組織腫瘍の線維腫症（fibromatosis）に 分類され4)，(1)分化した線維芽細胞の増殖，(2浸潤性発育， (3)増殖性細胞間の多量の膠原線維の存在，(4)細胞学的悪性 像や顕著な核分裂像の欠如，(5)転移をきたさないが浸潤性 で摘出術後も局所再発を繰り返すことが特徵で，臨床的に は良悪性境界になる る $^{5,6)}$. 発生頻度は 100 万人中 $2.4 \sim 4.3$ 人, 全新生物中 $0.03 \%$ で，腹壁・四肢に好発し腹腔内は全デス モイド中 $8 \%$ である ${ }^{7,8)}$. Familial adenomatous polyposis $(\mathrm{FAP})^{9)}$, Gardner 症候群 ${ }^{10)}$, 手術や外傷 ${ }^{11)}$ ，妊娠分娩後 に多く発症し，33\%にエストロゲン受容体が認められると の報告もあり，エストロゲンの関与 ${ }^{12)}$ が示唆される。自験 例の如く単独発生も散見される ${ }^{13,14)}$.

腸間膜デスモイドの術前の画像による質的診断は困難で ある。CTでは多くはほぼ均一な充実性腫瘤で，造影の程 度は様々である。MRI では T 2 強調像で高信号や不均一な 信号を呈し，高信号域は密な細胞成分，低信号域は疎な細 胞成分で膠原繊維が豊富な部分に相当する ${ }^{15)}$. 浸潤性の腸 間膜デスモイドの MRI 画像の形態的特徵は境界が不明瞭 となり，腸間膜脂肪織内で渦巻き状の軟部組織の肥厚を呈
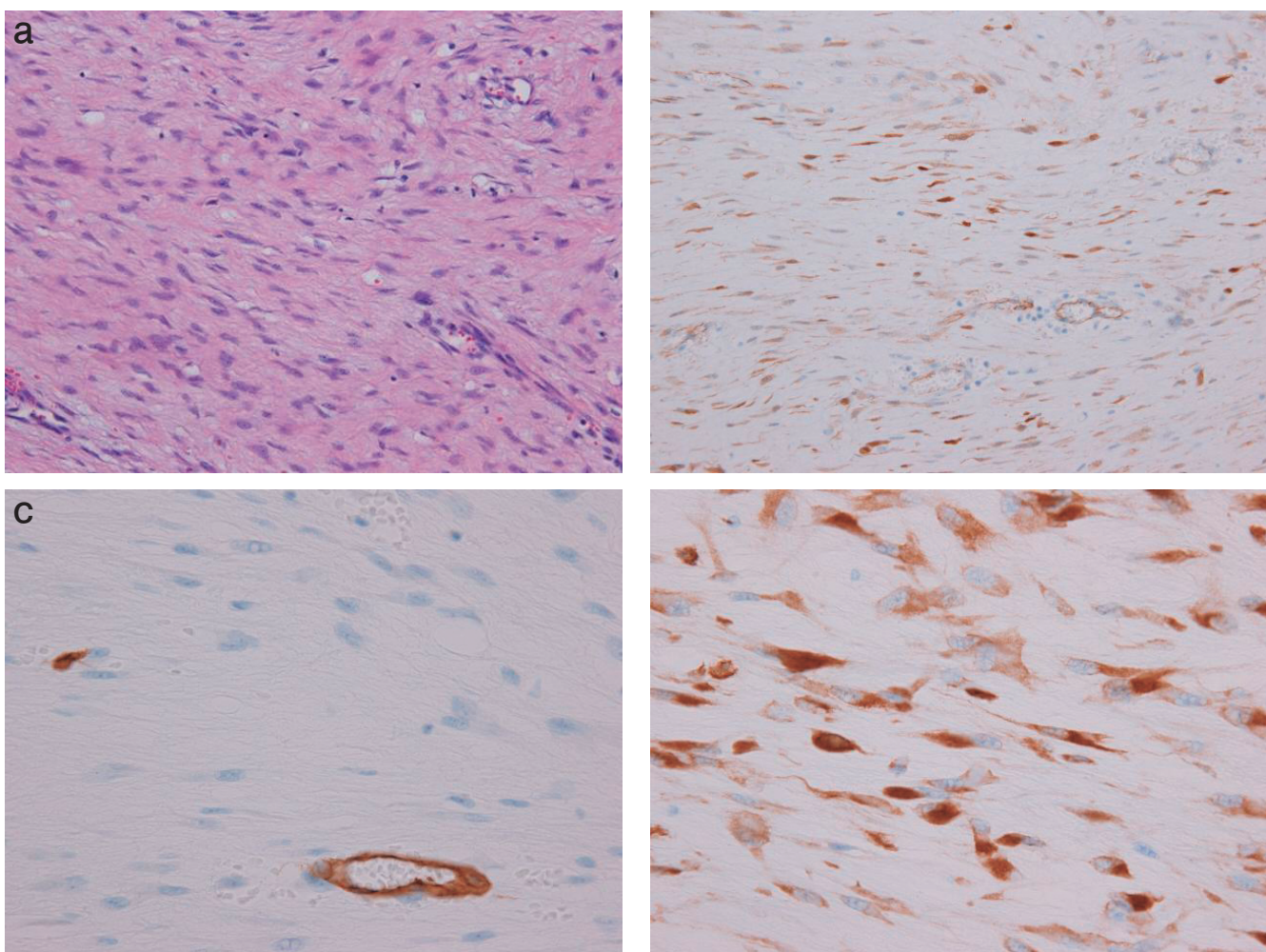

図 5 病理組織

$\mathrm{a}: \mathrm{HE}$ 染色. 腫瘍細胞は楕 円形の核と両染性の胞体をも つ細長い紡鍾形で Myofibroblastの形態で膠原線維と緩 やかな束をなし増生してい た。 $\mathrm{b}: \beta$-catenin 染色. 陽 性. c : CD34染色. 陰性. d：c-kit 染色. 陰性. 


\begin{tabular}{|c|c|c|c|c|c|c|c|c|c|c|c|c|c|c|c|c|c|c|c|c|c|c|c|c|c|c|}
\hline$a_{0}^{\infty}$ & \begin{tabular}{|l|l|} 
& 0 \\
& \\
\end{tabular} & \begin{tabular}{l|l|} 
& $\sigma$
\end{tabular} & \begin{tabular}{l|l}
0.17 \\
\end{tabular} & \begin{tabular}{|l|l|} 
& $\cong$ \\
\end{tabular} & $\approx \approx$ & & 合 & L & & \begin{tabular}{|l|l}
$a^{\prime}$ &
\end{tabular} & Q & \begin{tabular}{|l|l}
$*$ & 0
\end{tabular} & 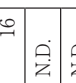 & $\dot{z}^{\circ}$ & $\begin{array}{ll}\sigma & \text { I }\end{array}$ & & $\because \unlhd$ & & 夽芸芸 & & & & $N \stackrel{N}{N}$ & ড & $\begin{array}{l}N \\
N\end{array}$ & $\vec{\triangle}: \triangle$ \\
\hline
\end{tabular}

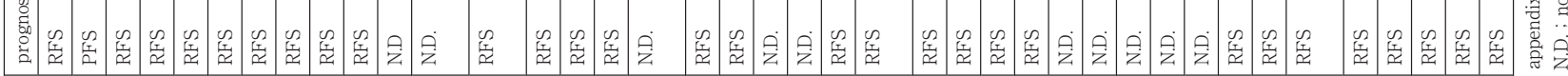

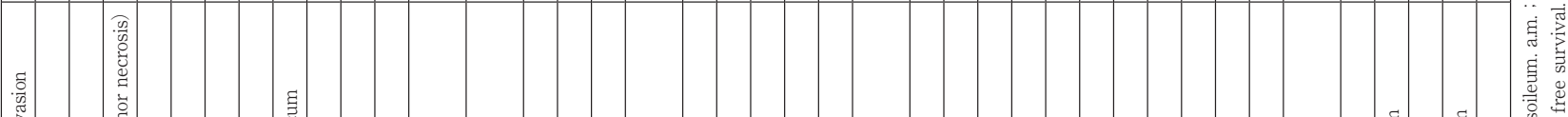

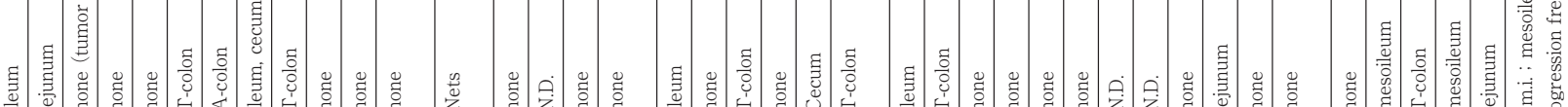

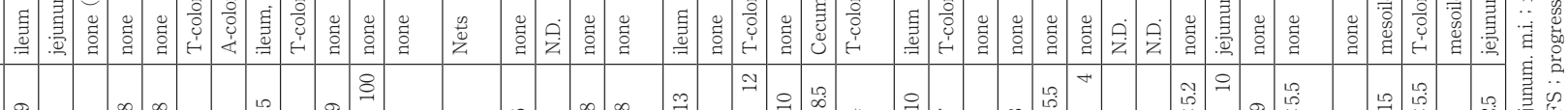

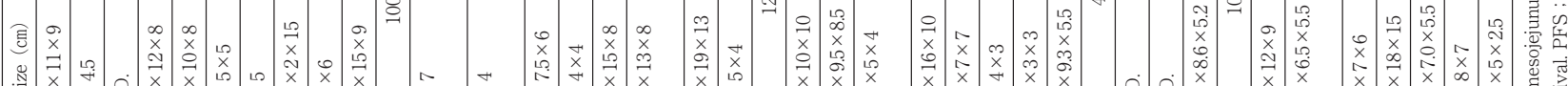

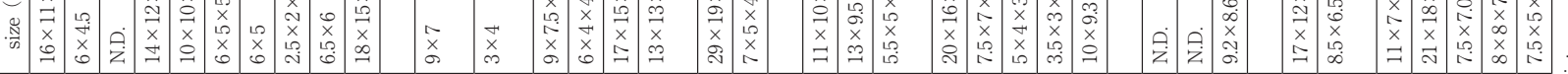

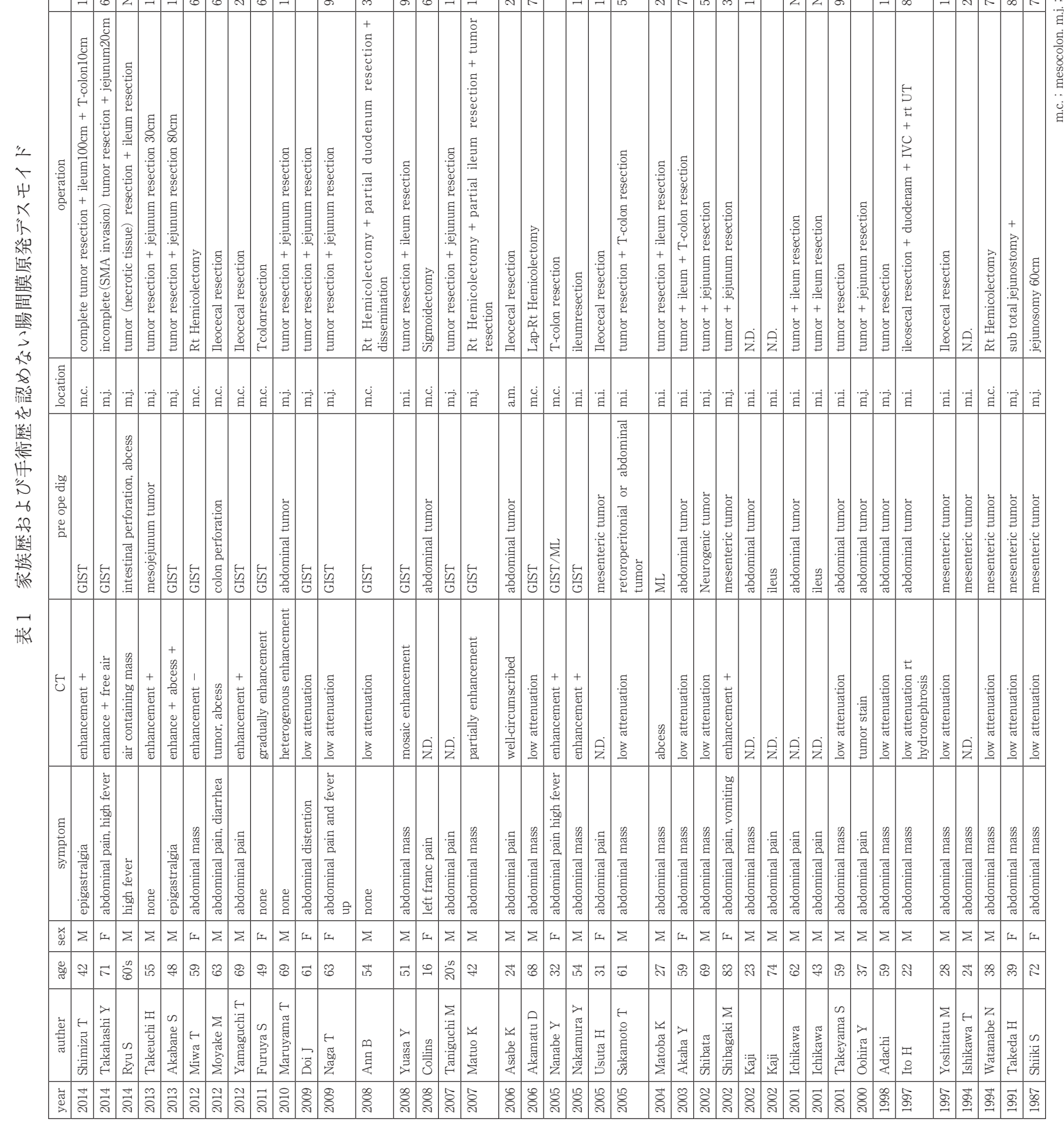

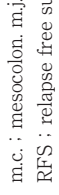


する。またしばしば間膜内で角ばった，あるいは鋸歯状の 形態を呈する ${ }^{16)}$. 自験例は, 内部はほぼ均一で, 辺縁は鋸 歯状を呈し, T2 強調画像の索状の低信号域は繊維組織, 比較的高信号域は繊維芽細胞と判断した。辺縁鋸歯状であ る点がGIST と, 置換増殖性にそしい点が悪性リンパ腫と 非典型的であった。

腹部手術既往および FAP の合併を認めない腸間膜デス モイド腫瘍の報告は少なく, 医学中央雑誌において2016年 までの期間で「デスモイド」「線維腫」「腸間膜」をキーワ ードに検索し, 腹部手術既往㧍よびFAP の合併を認めな いと記載のあったものは自検例を含め41例（表 1 ）であり これらについて検討を加えた。平均年齢は 48.5 歳（22～83 歳）であり，男性28例，女性13例で男性に多かった。発生 腸間膜部位は空腸16例 (39\%), 回腸13例 (32\%), 上行結 腸 4 例 ( $9 \%$ ), 横行結腸 3 例, 回盲部 2 例, S 状結腸 1 例, 虫垂 1 例, 不明 1 例であり小腸間膜発生が最も多かっ た. 腫瘍最大径は平均 $10.6 \mathrm{~cm}(2.0 \sim 29 \mathrm{~cm})$ で，41例中19例 は腹部腫瘤を主訴とし, 特徵的な臨床症状は認めなかった。 術前画像診断でデスモイド腫瘍が疑われた症例は自験例 以外では認めず，多くの症例で腸間膜腫瘍や小腸腫瘍や GIST など診断されていた.

治療は外科的切除が第一選択だが, 浸潤性に発育すると, 広範囲切除が必要となる ${ }^{17)}$. しかし完全切除の腹腔デスモ イド $22.2 \%$ に再発を認め ${ }^{18)}$, 根治切除不能でも予後に影響 しないことから，大量小腸切除はさけるべきであるとの見 解もある ${ }^{19)}$. 自験例では上腸間膜動脈と十分な margine を 確保できず，合併切除による小腸大量切除を回避した。

Deepak らによると，6 月月毎に理学所見と画像検索を最 低 3 年は継続すべきであり ${ }^{20)}$, 今後慎重に経過をみる必要 がある. 再発・切除不能例は薬物療法（非ステロイド性抗 炎症剂・抗エストロゲン㓮 ${ }^{21}$,, メシル酸イマチニブ22)）や 放射線療法 ${ }^{23)}$ あるいは, 抗エストロゲン剂やアントラサイ クリンと放射線療法が集約的に行われた報告がある ${ }^{24)}$ 。ま た腹腔内多発例には非ステロイド性抗炎症剂単剤が著効す るとされる ${ }^{25)}$.一方で Camargo らは切除標本中の免疫組織 学的検討ではエストロゲン受容体や C-Kit 蛋白の発現をさ ほど認めず，必ずしも抗エストロゲン剂やメシル酸イマチ ニブの効果とレセプターや蛋白の発現は相関しないとして いる26).このように再発時の治療法は多岐にわたるが現段 階で確立されておらず, 今後の症例の蓄積や研究が必要で ある。

\section{結 語}

術前診断にて画像所見から腸間膜デスモイドを第一に疑 ったため, 小腸大量切除を回避することが可能であった.
上腸間膜動脈と十分な surgical margine が確保できなか ったため, 今後慎重な経過観察を行う必要がある.

\section{文献}

1) Szenes A : ber solide Mesenterialtum-oren. Deutsch Z Chir (1918) 144, 228-249.

2) Judd ES, Larson LM : Retroperitoneal tumors. Surg Clin North Am (1933) 12, 823-834.

3 ) 山本誠己, 勝部宥二, 奥 勝次, 浦 伸三, 橋本雅夫, 他 : 原発 性膜血管肉腫の 1 例。臨床外科（1978）34，285-290.

4 ）河野 寛, 日向 理, 川井田博充, 板倉良平, 藤井秀樹：小腸間 膜原発デスモイド腫瘍の 1 切除例. 日臨外会誌 (2009) 70, 15311535.

5 ) Stout AP : Juvenile fibromatosis. Cancer (1954) 7, 953-978.

6 ) Ackerman LV : Fibromatosis ; in Surgical Pathology, vol 2, 6th edition, Rosai J (eds), CV Mosby Co., St.Louis (1981) 1415-1419.

7 ) Reitano JJ, Hayry P, Nykyri E, Saxén E : The desmoid tumor. Incidence, sex-, age- and anatomical distribution in the finnish population. Am J Clin Pathol (1982) 77, 665-673.

8 ) Suit HD : Radiation dose and response of desmoids tumors. Int J Radiat Oncol Biol Phys (1990) 19, 225-227.

9 ) Clark SK, Phillips RK : Desmoids in familial adenomatous polyposis. Br J Surg (1996) 83, 1494-1504.

10) Gardner EJ : A genetic and clinical study of intestinal polyposis, a predisposing factor for carcinoma of the colon and rectum. Am J Hum Genet (1951) 3, 167-176.

11）正村裕紀, 片岡昭彦, 富岡伸元, 高橋典彦, 佐藤裕二, 他：腹腔 デスモイド腫瘍の 2 例。 日臨外会誌（2008）69，936-940.

12) Lim CL, Walker MJ, Mehta RR, Das Gupta TK : Estrogen and antiestrogen binding sites in desmoid tumors. Eur J Cancer Clin Oncol (1986) 22, 583-587.

13) Bruce JM, Bradley EL 3rd, Stachidanand SK : A desmoid tumor of the pancreas. Sporadic intra-abdominal desmoids revisted. Int J Pancreatol (1996) 19, 197-203.

14）安炳九, 望月能成, 清水泰博, 伊藤誠二, 小森康司, 他：手術既 往無く腸間膜および大網に発生した多発性腹腔内デスモイド腫 瘍の 1 切除例. 日臨外会誌 (2008) 69, 461-465.

15）谷口尚範, 岩間祐基, 杉森智亜紀, 今葷倍敏行, 伏見育崇, 他 : 腸間膜デスモイド腫瘍の画像診断. 臨床放射線 (2002) 47, 18361842.

16) Azizi L, Balu M, Belkacem A, Lewin M, Tubiana JM, et al. : MRI features of mesenteric desmoid tumors in familial adenomatous polyposis. AJR Am J Roentgenol (2005) 184, 1128-1135.

17) Middleton SB, Phillips RK : Surgery for large Intra-abdominal desmoid tumors : report of four cases. Dis Colon Rectum (2000) 43, 1759-1763.

18) Burke AP, Sobin LH, ShekitKa KM : Mesenteric fibromatosis. A follow-up study. Arch Pathol Lab Med (1990) 114, 832-835.

19) Smith AJ, Lewis JJ, Merchant NB, Leung DH, Woodruff JM, et al. : Surgical management of intra-abdominal desmoids tumors. Br J Surg (2000) 87, 608-613.

20) Venkat D, Levine E, Wise WE : Abdominal Pain and Colonic 
Obstruction From an intra-abdominal desmoid tumor. Gastroenterol Hepatol (NY) (2010) 6, 662-665.

21）河島秀昭, 石後岡正弘, 原 隆志, 樫山基矢, 高梨節二, 他 : Tamoxifen と sulindac が奏効した骨盤壁デスモイド腫瘍の 1 例. 日臨外会誌 (2004） 65, 1715-1718.

22）藤江裕二郎, 山本浩文, 池田正孝, 大植雅之, 関本貢嗣, 他 : 切 除後再発を繰り返す腹腔内デスモイド腫瘍に対してメシル酸イ マチニブを使用した 1 例. 手術（2004）58，1789-1792.

23) Oohata Y, Mibu R, Uehara S, Iida M, Ishikawa M, et al. : Regression of an aggressive abdominal desmoid tumor in a patient with familial adenomatous polyposis by hyperthermo radiotherapy. Am J Gastroenterol (1997) 92, 156-158.
24) Tanaka K, Yoshikawa R, Yanagi H, Gega M, Fujiwara Y, et al. : Regression of sporadic intra-abdominal desomid tumor following administration of non-steroidal anti-inframmatory drug. World J Surg Oncol (2008) 6, 17.

25) de Camargo VP, Keohan ML, D’Adamo DR, Antonescu CR, Brennan $\mathrm{NF}$, et al. : Clinical outcomes of systemic therapy for patients with deep fibromatoses (desmoid tumors). Cancer (2010) 116, 22582265 .

26) Leithner A, Gapp M, Radl R, Pascher A, Krippl P, et al. : Immunohistochemical analysis of desmoids tumors. J Clin Pathol (2005) 58, 1152-1156. 